\title{
FASILITAS EDUTAINMENT: PERPUSTAKAAN FIKSI HIJAU DAN RUANG SENI PERTUNJUKAN DI BUMI SERPONG DAMAI
}

\author{
Michelle Ashikin ${ }^{1)}$, Tatang Hendra Pangestu ${ }^{2)}$ \\ 1) Program Studi S1 Arsitektur, Fakultas Teknik, Universitas Tarumanagara, michelle.ashikin@gmail.com \\ 2) Program Studi S1 Arsitektur, Fakultas Teknik, Universitas Tarumanagara, tatang_pangestu@hotmail.com
}

\begin{abstract}
Abstrak
Proyek Fasilitas Edutainment merupakan fasilitas yang menggabungkan fungsi edukasi dan entertainment, sebagai tanggapan pada isu Virtual Third Place yang kemudian menyebabkan buku konvensional dan perpustakaan sendiri telah mulai ditinggalkan. Padahal, minat baca dan ekspektasi masyarakat terhadap perbaikan perpustakaan masih tinggi. Pada proyek ini, dengan memanfaatkan konteks pada kawasan pendidikan Edutown di Bumi Serpong Damai, perpustakaan di-redefinisikan kembali dengan tipologi design yang berbeda dan dibuat khusus untuk buku fiksi untuk meng-highlight fungsi hiburannya. Dengan mengangkat konteks reading for pleasure dan menambah program kesenian, diharapkan proyek dapat memperbesar kapasitasnya sebagai ruang komunal yang memiliki sense of place sebagai third place. Konsep ruang yang diambil berupa garden library, dimana ruang hijau tapak dimanfaatkan sebagai elemen pembentuk ruang pada proyek sehingga pengguna dapat merasakan pengalaman membaca dengan suasana taman, dengan orientasi pada ruang outdoor. Program utama yang disediakan digolongkan pada fungsi literasi (perpustakaan dan pelatihan penulisan) serta fungsi kesenian (seni pertunjukan dan pelatihan kesenian). Dalam perancangan, metode tipologi digunakan untuk mempelajari perubahan pada perpustakaan, sehingga bentuk arsitekturalnya dapat menjadi berbeda dan keluar dari stereotype-nya. Wujud yang ditampilkan dalam bentuk ruang arsitektural merupakan stacking/ super-imposed dari tipe archetype, prototype dan stereotype- nya, yang dimaksudkan untuk dapat menginterpretasikan kembali pandangan pengguna terhadap desain perpustakaan di era yang lebih modern.
\end{abstract}

Kata kunci: edutainment; fiksi; hijau; perpustakaan; tipologi

\begin{abstract}
Edutainment Facility is a project that combines education and entertainment, as a response in the issue of virtual third place that causes a shifted user preferences, led to decreasing use of conventional books and libraries. The project brings forward the contextuality of the site itself which functioned as an integrated - educational area in Bumi Serpong Damai, to redefine the library using a new and distinctive typology design and especially provide fiction books to highlighted its entertaining quality. By 'reading for pleasure' theme and adding art as supporting program, the project is intended to broaden its purpose as communal place or third place. The concept of 'garden library' delivered by preserving the greeneries and explore its potency to create its building element, aiming to provide user of a garden-reading experience which orientated to outdoor space. Main program can be separated to 2 function, first is literation which include library and course, and art as supporting function. In the terms of design, typology method is applied to learn changes in libraries, therefore making the design output to be different from the stereotype that usually being used today. Architectural form is a result of stacking the tipology type - archetype, prototype and stereotype - which aim to re-interpreting the users viewpoint of libraries in modern era.
\end{abstract}

Keywords: edutainment; fiction; garden; library; typology 


\section{PENDAHULUAN}

\section{Latar Belakang}

Proyek dilatar-belakangi oleh isu virtual third place yang menyebabkan perubahan pada sarana mengakses media informasi, yaitu dari buku konvensional (perpustakaan) menjadi $e$ book dan internet. Akibatnya, popularitas dari perpustakaan menurun dan perkembangannya terhambat. Stagnansi perkembangan perpustakaan ini menjadi suatu urgensi, dimana perpustakaan di Indonesia sendiri dapat digolongkan masih seumur jagung dan masih memiliki masalah internalnya sendiri. Padahal, perpustakaan dipercaya dapat meningkatkan kualitas dari sebuah komunitas dan masih dibutuhkan meski banyak yang telah beralih ke informasi digital (Pew Research Center, 2016).

Studi yang dilakukan Asosiasi Penjual Buku Inggris \& Irlandia mengatakan bahwa pemakaian ebook melalui internet naik 318\% pada tahun 2018 dan diperkirakan $50 \%$ dari buku yang terjual dalam waktu 10 tahun mendatang adalah buku digital, diikuti dengan penurunan jumlah penjual buku dan perpustakaan. Hal ini sangat disayangkan, mengingat perpustakaan memiliki potensi yang besar sebagai ruang ketiga, dimana saat ini banyak perpustakaan yang sukses berkembang dengan meningkatkan fungsinya menjadi ruang sosial (Bryson, 2003).

Berdasarkan studi hasil riset picodi.com terhadap transaksi di toko buku yang dilakukan pada Maret 2019, 7.800 responden dari 41 negara mengatakan bahwa ${ }^{1}$ genre yang paling diminati adalah genre fiksi (75\%), thriller (33\%) dan fantasi (31\%). Dalam hal ini, perancang ingin meredefinisikan kembali fungsi perpustakaan yang bukan hanya mengedukasi, namun juga menghibur dengan mengkhususkan genre pada buku fiksi sehingga mengangkat konteks reading for pleasure (membaca untuk kesenangan).

Data menunjukan bahwa mahasiswa dan pengguna dengan rentang umur 25-44 tahun adalah pengunjung perpustakaan reguler. Hal ini didukung oleh kawasan Edutown di Bumi Serpong Damai, dimana ruang kedua (second place) di dominasi oleh universitas dan sekolah, sehingga dapat menarik pelajar dan mahasiswa sebagai pembelajar literasi untuk menjadi pengguna utamanya. Selain itu kawasan juga didominasi hunian pelajar dan perumahan sebagai first place-nya dengan demografi pengguna yang cocok. Hasil dari design yang dicapai diharapkan dapat menjadi preseden dalam pembangunan perpustakaan di masa yang akan datang, terutama dalam fungsinya sebagai ruang ketiga.

\section{Rumusan Permasalahan}

${ }^{2}$ Pada tahun 2015, Online Computer Library Center (OCLC) mengadakan survey dengan total responden 3348 orang dari enam negara. $72 \%$ responden berstatus mahasiswa memilih opsi search engines sebagai sumber informasi ketimbang langsung berkunjung ke perpustakaan $(14 \%)$ atau mengakses online library (10\%). Hal ini memperlihatkan kecenderungan library visit yang tidak meningkat, malah cenderung mengalami penurunan (Pew Research Centre,2016).

Di Indonesia, permasalahan pada perpustakaan yaitu:

a. Perpustakaan tidak tanggap terhadap tren. Perpustakaan masih dibungkus dengan gaya yang formal dan tidak menarik, dan menimbulkaan keenganan untuk datang.

b. Perpustakaan tidak berinovasi pada fungsi pemberdayaan masyarakat sebagai ruang komunitas, program terbatas hanya seputar membaca.

c. Pengguna terbentur oleh banyaknya regulasi

d. Dimiliki hanya oleh pemerintah/ institusi sehingga sulit diakses.

e. Kurangnya perhatian pada konteks reading for pleasure.

\section{Tujuan}

\footnotetext{
1 Picodi. (15/04/2019). Pembelian Buku di Indonesia (dan di seluruh Dunia).

${ }^{2}$ De Rosa,C., Joanne C. (2005) Perceptions of Libraries and Information Resources. Dublin, Ohio:
} 
a. Merespon tuntutan akan inovasi baru dalam library experience.

b. Mengembalikan popularitas perpustakaan untuk mengimbangi kemajuan teknologi dan meningkatkan peluang kerja di bidang penulisan dan pertunjukan.

c. Mengedukasi generasi masa kini dalam bidang seni literasi dan pertunjukan, serta meningkatkan konseptualitas karya-karya yang dihasilkan.

\section{KAJIAN LITERATUR}

\section{Third Place}

Istilah third place (ruang ketiga) mulai diperkenalkan oleh Ray Oldenburg dalam bukunya yang berjudul ${ }^{3}$ The Great Good Place (1989). Oldenburg membagi tempat dimana manusia menjalani kehidupan sehari-harinya menjadi tiga yaitu first place, second place, dan third place. First place adalah rumah, second place adalah tempat dimana masyarakat banyak menghabiskan waktu sesuai tuntutan profesinya, dan third place adalah tempat selain first place dan second place yang menjadi wadah suatu komunitas untuk saling bertukar ide dengan gaya informal yang menjadi "the core settings of informal public life". Oldenburg (1989: 16) mendefinisikan third space sebagai ruang informal / ruang publik diluar dari rumah dan tempat kerja, yang dapat mengakomodasi aktivitas mulai dari aktivitas yang bersifat keseharian, sukarela, informal dan menyenangkan bagi individu dan komunitas. Selain itu, disebutkan juga bahwa perpustakaan sebagai learning space sudah memiliki kualitas yang harus dimiliki oleh sebuah ruang ketiga karena mengakomodasi kegiatan belajar pada lingkungan yang suportif, dimana ide akan lebih diutamakan daripada status dan argumentasi diekspresikan melalui kegiatan diskusi.

\section{Perkembangan Third Place secara Spasial - Indoor to Outdoor}

${ }^{4}$ Perkembangan third place di Indonesia berkembang sekitar tahun 2004 setelah munculnya mall sebagai simbolisasi dari gaya hidup lebih modern. Di tahun 2010, café, coffee shop, resto mulai mengisi ruang kota dan mulai saling beradu konsep sehingga penggunaan third place sebagai ruang indoor mulai beralih ke ruang outdoor seperti taman, jalan, atap bangunan dsb. Ruang outdoor mulai mengalami transformasi menjadi tempat (place) yang mengakomodir aktivitas sosial, seni budaya, komunitas, dan ekonomi, baik itu terencana maupun tidak terencana. Begitu juga dengan taman kota, yang semula dianggap sebagai ruang terbuka kota menjadi ruang berkumpul dan rekreasi.

\section{Perpustakaan Fiksi}

- 'Perpustakaan' (Yunani : library) dibentuk dari kata dasar 'pustaka' yang artinya 'buku'. Menurut Kamus Besar Bahasa Indonesia, Perpustakaan diartikan sebagai "kumpulan bukubuku (bahan bacaan, dsb)."

- 'Fiksi' menurut KBBI adalah cerita rekaan / khayalan yang tidak berdasarkan kenyataan (roman, novel, dan sebagainya).

Sehingga disimpulkan bahwa perpustakaan fiksi merupakan sebuah tempat yang memuat kumpulan karya yang tidak berdasarkan kenyataan, baik karya tulis / cetak/ rekam yang disusun sedemikian rupa untuk memenuhi kebutuhan penggunanya.

\section{Seni}

Secara umum, seni dapat dibagi menjadi 5 cabang berdasarkan unsurnya:

a. Seni Suara dengan unsur utamanya suara, misalnya: suara manusia, suara alat musik, dsb.

b. Seni Tari dengan unsur utamanya gerak.

c. Seni Teater disajikan dengan akting meliputi bahasa, gerak, dan musik.

d. Seni Sastra dengan unsur utama bahasa.

\footnotetext{
${ }^{3}$ Oldenburg, Ray (1989). The Great Good Place. New York: Paragon House.

${ }^{4}$ Andi Jaya, Meldo. (2018). Transformasi Tempat Ketiga (Third Place). Jurnal Arsir Universitas Muhammadiyah Palembang, Vol.2 (1), E-ISSN 2614-4034.
} 
e. Seni Rupa dengan unsur utamanya adalah unsur-unsur rupa.

Dalam penerapannya, kelima cabang seni ini hanya dibagi menjadi 3 yaitu seni pertunjukan (performing art - teater, tari dan musik), seni sastra (literature art) dan seni rupa (visual art).

\section{Desain Perpustakaan}

Desain perpustakaan menggunakan pedoman yang diambil dari ${ }^{5}$ Data Arsitek Jilid 2 (Ernst Neufert, 2002), terutama dalam penentuan struktur dan ergonomi dari perabot perpustakaan.

- Luas minimum perpustakaan adalah $96 \mathrm{~m} 2$ dan minimal $300 \mathrm{~m} 2$ per 10.000 jilid media.

- Jarak ideal struktur misalnya 7,20 x 7,20 m dengan ketinggian bebas lantai ringan 3m.

- Jalan utama 1,5-2 m dan lebar jalan rak 0,75 m, tangga dicapai dalam jarak $38 \mathrm{~m}$.

- Jarak rak buku adalah 1,5-2,3 m, maksimal rak $3 \mathrm{~m}$. Jarak antar rak adalah 60-75 cm.

- Panjang rak 91-100 cm. Kedalaman papan rak 20-25 cm. Tinggi rak 1,5-1,8 m.

\section{METODE}

Metode yang digunakan adalah tipologi, yaitu mengkaji tentang tipe. Tipe berasal dari kata Bahasa Inggris yaitu type, yang dalam Latin Akhir berarti sebuah sosok atau pola berulang. Dalam dunia arsitektural, tipe berarti klasifikasi sistematik berdasarkan karakter fisik. ${ }^{6}$ Penggunaan metode tipologi yaitu dengan mempelajari tipe bangunan sebagai asal usul sesuatu yang mengandung unsur-unsur yang tidak dapat dikurangi lagi sehingga dapat berciri. Ciri inilah yang digunakan untuk memperoleh design baru perpustakaan sehingga dapat menghadirkan esensi third place.

Sebagai suatu metode, tipologi menganalisa setiap perubahan objek arsitektural yang menyangkut bangun dasar, sifat dasar, serta proses perkembangan bangun dasar tersebut sampai ke bentuk yang sekarang serta fungsi dari objek tersebut. Dalam menganalisa, penulis berpedoman pada sumber buku Metode Perancangan (Gunawan Tjahjono, 2002) dan menganalisa beberapa poin kajian sesuai buku ${ }^{7}$ Precedent In Architecture (Roger H. dan Michael P., 1996). Pokok yang dianalisa berupa bentuk ruang, hirarki ruang, komposisi luas, penggunaan ruang hijau, blok massa, potongan, serta repetitisi dan keunikan. Hasil dari metode ini digunakan sebagai panduan dalam menyusun konsep bentuk dan sirkulasi sehingga tercermin secara fisik dalam gambar rancangan. Hasil dari studi tipologi :

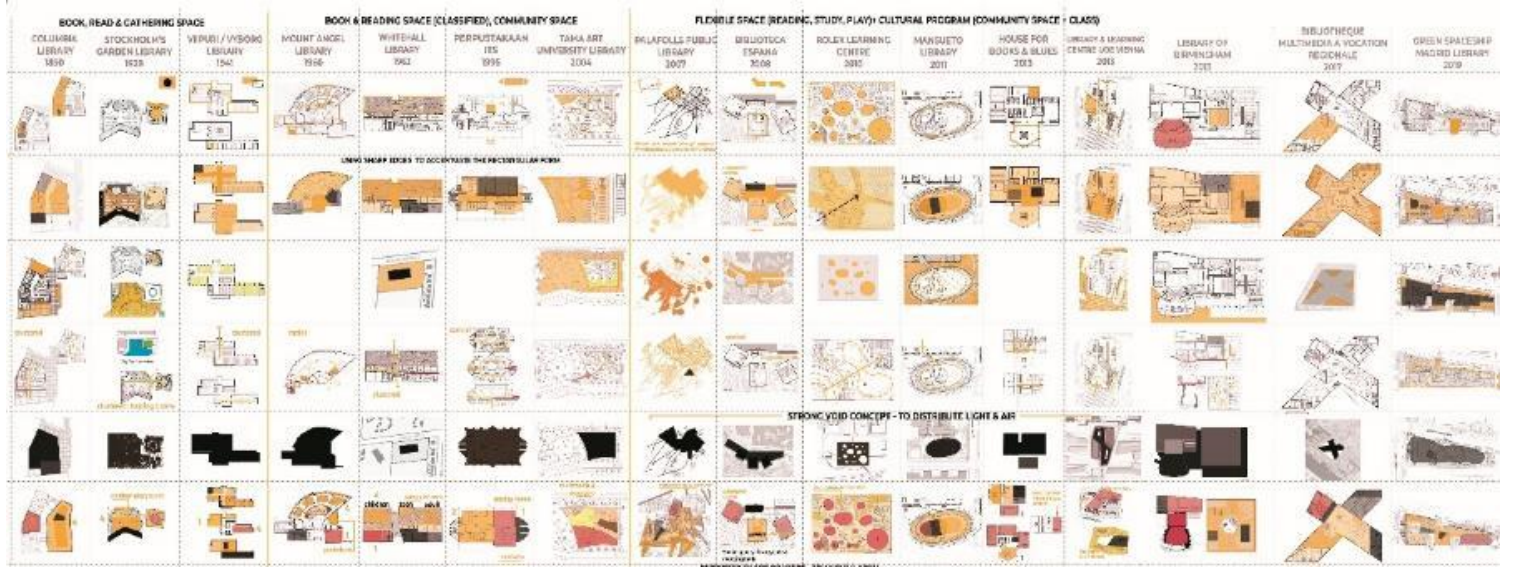

Gambar 1. Studi Tipologi

Sumber: Penulis, 2019

\footnotetext{
${ }^{5}$ Neufert, E. (2002). Data Arsitek Jilid 2 (Edisi Kedua). Jakarta : Erlangga.

${ }^{6}$ Rossi, A. (1991). Architecture of The City. M.I.T Press : Massachusetts.

${ }^{7}$ Clark, R. H. dan Michael P. (1996). Precedent In Architecture. Canada: New Jersey
} 
Setelah mengkaji tipe-tipe perpustakaan \& ruang seni pertunjukan, selanjutnya menentukan lokasi untuk proyek yang diusung berdasarkan beberapa kriteria. Lokasi tapak dipilih melalui analisis secara kawasan dari makro hingga mikro. Dalam survey yang dilakukan oleh BPS tahun 1998-2018, jumlah penduduk di daerah Tangerang (outer zone) dan penyangga lainnya cenderung naik secara signifikan. Hal ini dapat mengindikasikan tingkat perkembangan kawasan permukiman - first place, perkantoran - second place, entertain, dan sarana-prasarana.

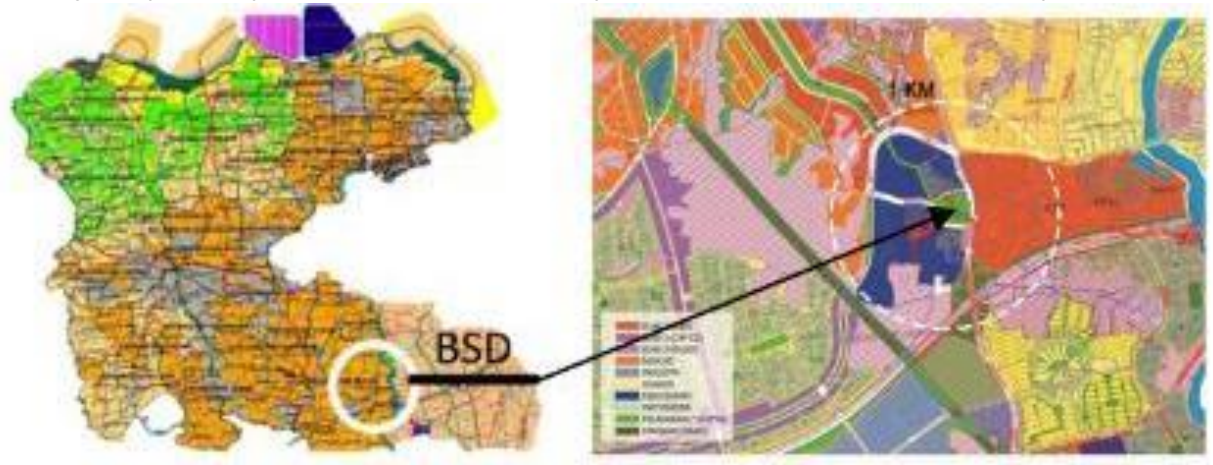

Gambar 2. Peta Tata Ruang

Gambar 3. Peta Peruntukan CBD 55

Sumber: https://tangerangkab.go.id, 2019 Sumber: Data autocad oleh pengembang, 2019

Tangerang bagian selatan dipilih karena fungsinya sebagai kawasan kota (warna oranye) dibanding dengan bagian utara yang merupakan areal agraris. Secara hirarki, daerah Pagedangan di Tangerang bagian selatan mulai berkembang menjadi Pusat Kegiatan Wilayah (PKW) yang memiliki akses langsung ke daerah Jakarta sebagai Pusat Kegiatan Nasional (PKN).

Kecamatan Serpong memiliki potensi demografi, dimana penduduk terbanyak adalah umur 25 - 39 tahun yang merupakan usia produktif, diikuti umur 5-19 tahun yang merupakan pelajar (Kabupaten Tangerang dalam Angka, 2018). Hal ini didukung oleh BSD City yang saat ini berkembang secara infrastruktur dan terdapat animo BSD sebagai kota yang ditujukan untuk pelajar dan pekerja, dengan potensi pengembangan business district dan universitas sehingga cocok untuk menunjang pembentukan third place berbasis edukasi.

Saat ini BSD sedang mengembangkan area CBD 55 yang meliputi perumahan seperti Foresta dan The Icon, kawasan Edu-Town yaitu kawasan pendidikan yang terintegrasi, dan BSD Green Office Park, yaitu suatu kompleks perkantoran dengan kawasan hijau terbuka. Posisi tapak terpilih berada di sentral dari kawasan Edutown itu sendiri (Gambar 3, zona warna hijau).

Tapak dipilih atas dasar kedekatan dengan :

\section{a. Kedekatan dengan perumahan - first place}

Tempat tinggal di sekitar tapak di dominasi oleh kos-kosan dan apartemen yang dapat ditempuh dengan berjalan kaki $(600 \mathrm{~m})$. Selain itu terdapat rumah-rumah berbentuk cluster yang dapat ditempuh kurang dari 2 km (bersepeda kira-kira 10 menit). Kedekatan ini strategis dengan subjek target proyek yaitu mahasiswa.

\section{b. Kedekatan dengan fungsi edukasi \& perkantoran - second place}

Menurut Time Saver Standards (Watson, 2003), perpustakaan sebaiknya dekat dengan institusi pendidikan, universitas dan sekolah agar saling menunjang satu sama lain.

\section{c. Kedekatan dengan titik kumpul komunitas - entertainment}

Area yang ramai pada BSD dapat ditemui di sekitar pusat perbelanjaan atau tempat kuliner. Konsep tempat 'nongkrong' yang ditawarkan kebanyakan berbentuk ruang outdoor beratap yang menawarkan aktivitas beragam. Kegiatan berbincang intensif juga terjadi di ruko-ruko, kantin, bistro, coffee shop sekitar lingkungan sekolah. Tempat-tempat tersebut memiliki keunikan pada design ruang yang menarik. Untuk keluarga, third place yang paling sering didatangi adalah yang ramah anak dan dilengkapi children playground. Misalnya pada taman kota, taman bermain dsb. 


\section{d. Kedekatan dengan area parkir bersama \& moda transportasi}

Kondisi tidak ramai seperti BSD yang jarang terjadi kemacetan cukup menguntungkan bagi proyek yang mengundang pendatang dengan waktu berkunjung yang lama, serta dapat mengurangi alokasi lahan parkir dan mengurangi sirkulasi mobil dalam tapak.

Berikut spesifikasi data tapak:

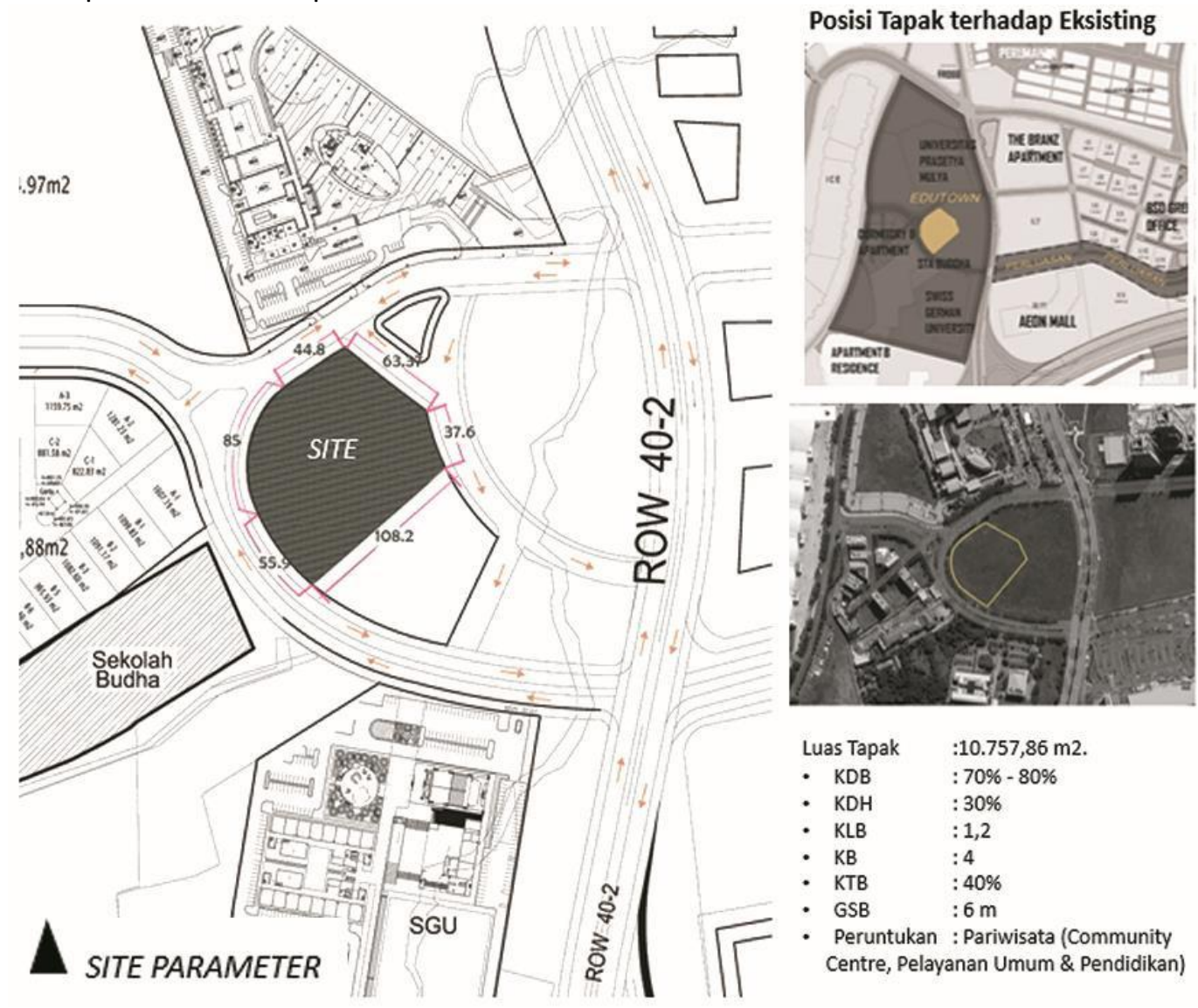

Gambar 4. Spesifikasi dan Data Tapak

Sumber : Data autocad kawasan oleh pengembang, 2019

Tabel 1. Hasil Analisa SWOT Tapak

\begin{tabular}{lll}
\hline Strength & - & Berlokasi pada sentral Edutown, sehingga target user-nya pasti \\
& - & Hubungan dengan fasilitas sekitar tapak sangat terbuka \\
& - & Memiliki bagian muka yang luas, aksesibel dari berbagai arah \\
& - & Adanya traffic pada area crossing dari kampus sehingga \\
& & memungkinkan adanya boulevard \\
Weakness & - & Ukuran tapak yang cukup luas memungkinkan pengolahan \\
& - & Orientasi tapak ke arah Barat \\
\hline Opportunity & - & Fasilitas yang tersedia dalam kota sudah cukup lengkap \\
& - Memiliki banyak lahan luas \\
& - Harga tanah masih cenderung murah \\
& - & Belum seramai pusat kota sehingga jarang terjadi kemacetan \\
\hline Threat & - Kesulitan pencapaian dari pemberhentian kendaraan umum
\end{tabular}

Sumber : Penulis, 2019 


\section{DISKUSI DAN HASIL}

Hasil penelitian berupa kajian mengenai metode tipologi dengan pendataan 20 bangunan yang dikaji dari berbagai aspek. Aspek yang dikaji berkaitan dengan elemen utama pada perancangan perpustakaan yang didata dengan teknik Precedent in Architecture yaitu repetitif ke unik, hirarki, sumber alami, sikulasi, massa, komposisi ruang, dan potongan. Selanjutnya, perancang dapat menentukan konsep bentuk yang baru pada perpustakaan, yaitu melalui teknik super-impose / layering dalam menentukan gubahan massa.
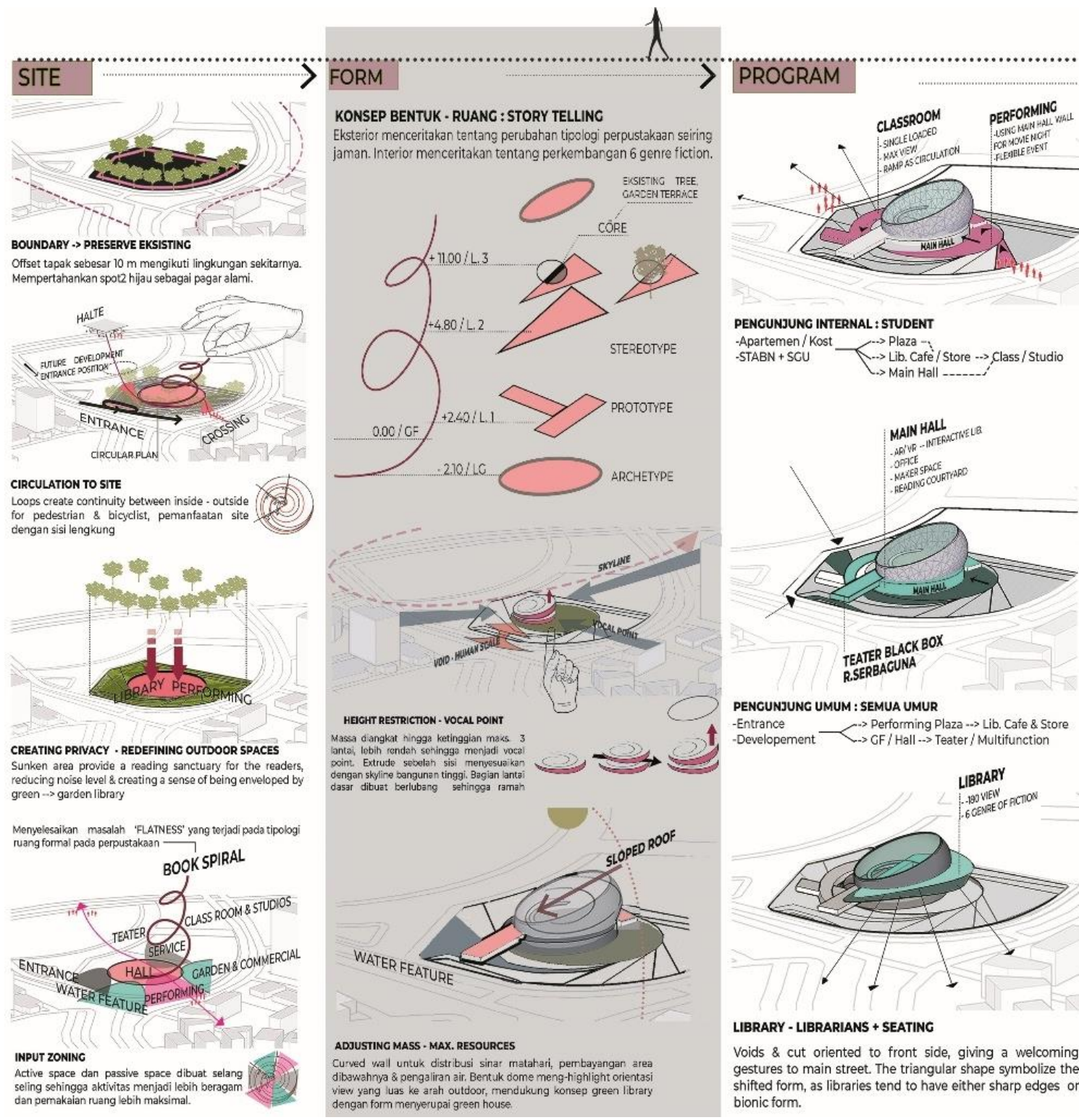

Mempertahankan spot2 hijau sebagai pagar alami.

CIRCULATION TO SITE

Loops create continuity between inside - outside for pedestrian \& bic

Gambar 5. Proses Gubahan Massa

Sumber: Penulis, 2019

Gubahan massa dibagi menjadi tahap desain tapak, desain bentuk dan input program. Desain tapak difokuskan untuk mempertahankan ruang hijau sekaligus sebagai pembentuk sirkulasi radial ke dalam tapak. Ruang hijau ini kemudian diangkat menjadi elemen pembentuk ruang dan tiap ruang hijau memiliki fungsinya sendiri sebagai fungsi ekstensi dari bangunan sekitarnya.

Bentuk mengikuti bentuk asli dari hasi studi tipologi yang dimodifikasi terutama pada bagian atap miring sehingga ramah terhadap iklim tropis, serta memiliki ketinggian yang ramah terhadap skala manusia. Kemudian program di input ke dalam bentuk massa dengan memerhatikan sirkulasi pengunjung umum, internal dan pengelola. 
Program ruang berasal dari perpaduan beberapa studi preseden. Secara garis besar, maka program ruang dan pembagian luas untuk perancangan adalah sebagai berikut :

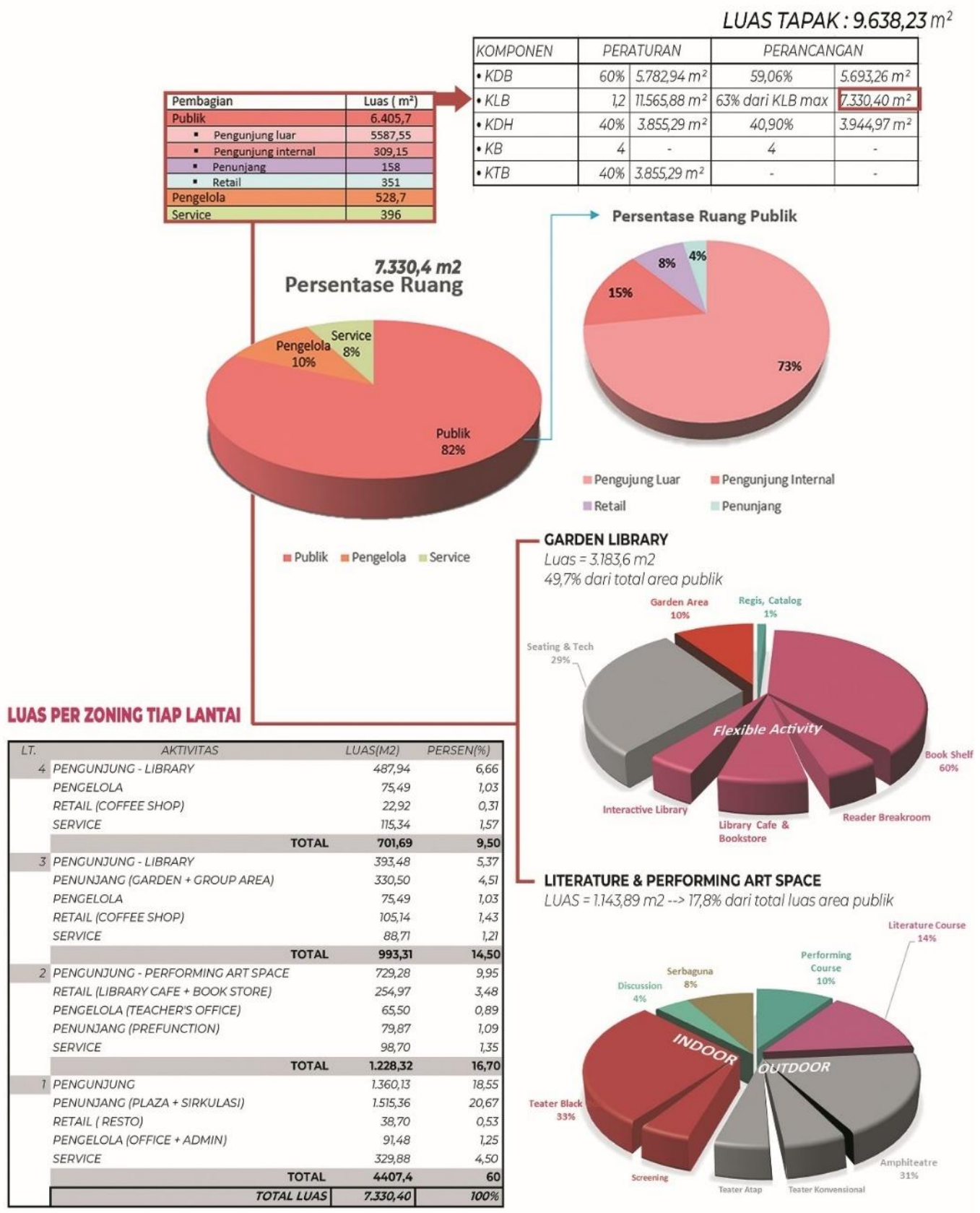

Gambar 6. Perhitungan Luasan Perancangan dan Program Ruang Sumber: Penulis, 2019

Konsep perancangan difokuskan pada pengolahan form dengan metode tipologi dan super imposition sehingga menghasilkan olahan ruang interior yang unik dan apa adanya. Hasil dari studi tipologi menghasilkan kesimpulan terhadap archetype, prototype dan stereotype :

- Prototype : bentuk awal dari perpustakaan didominasi bentuk kotak (persegi panjang), dimana awalnya perpustakaan hanya berfungsi sebagai gudang penyimpanan buku. Kemudian berkembang sebagai ruang untuk para pembelajar (scholar / orang terdidik) sampai akhirnya menjadi ruang diskusi dan pertemuan. Kesemua aktivitas ini di dominasi bentuk awal persegi panjang. 
- Stereotype : stereotype dari perpustakaan adalah pada penggunaan sudut lancip, dimana saat ini perancang mulai berimprovisasi dengan mendistorsi bentuk kotak tersebut dengan beberapa tujuan, yaitu supaya berfungsi sebagai icon melalui langgam hingga bidang curam, mendefinisikan gaya baru untuk sebuah ruang dari formal ke non formal. Seiring dengan perkembangannya menjadi ruang sosial atau diskusi, orientasi ruang bergeser dari buku menuju lingkungan sekitar (dari indoor to outdoor). Ditandai dengan banyak penggunaan material kaca dan kisi.

- Archetype : bentuk ideal pada perpustakaan. Seiring dengan perkembangan fungsinya yang bergeser dari book movement ( sirkulasi mengikuti rak buku yang berbentuk persegi) menuju kepada human movement ( pergerakan manusia), maka bentuknya turut menjadi fluid mengikuti gerak manusia dan mengarah pada bentuk sirkular. Hal ini dapat terlihat pada bagian void bangunan yang biasanya menjadi sentral dari sebuah perpustakaan dimana posisi pencahayaan alami menjadi krusial sebagai elemen pembentuk ruang.

Ketiga bentuk ini dipadukan dengan teknik super-impose yang menggunakan sistem layer yang ditumpuk-tumpuk. Dalam hal ini, penulis menggunakan konsep layer yang berkaitan dengan Space, Event dan Movement :

- Space ditentukan oleh metode tipologi dengan menumpuk archetype, prototype dan stereotypenya. Bentuk yang dihasilkan dengan "seadanya"

- Event dengan overlapping antara fungsi. Misalnya perpustakaan di lantai 1 indoor dan performing di lantai 1 outdoor. Pada lantai atasnya, lokasi zoning ini di digeser sehingga fungsi perpustakaan dapat "tergabung" dengan performingnya secara vertikal. Kemungkinan kombinasi program di setiap lantainya ini dimungkinkan dengan penggunaan jembatan, ramp, void hingga ruang hijau.

- Movement yang di super-impose adalah antara bentuk sirkulasi linear dan sirkulasi radial. Movement ini menjadi menarik karena secara eksperimental, sirkulasi linear ini diperuntukan untuk ruang seni yang dinamis, sedangkan sirkulasi radial diperuntukan untuk perpustakaan yang lebih formal.

Hasil ini dari konsep tersebut dapat dilihat dalam penggunaan denah, tampak serta potongan bangunan, dimana terdapat kombinasi bentuk dari persegi panjang, lingkaran dan segitiga.
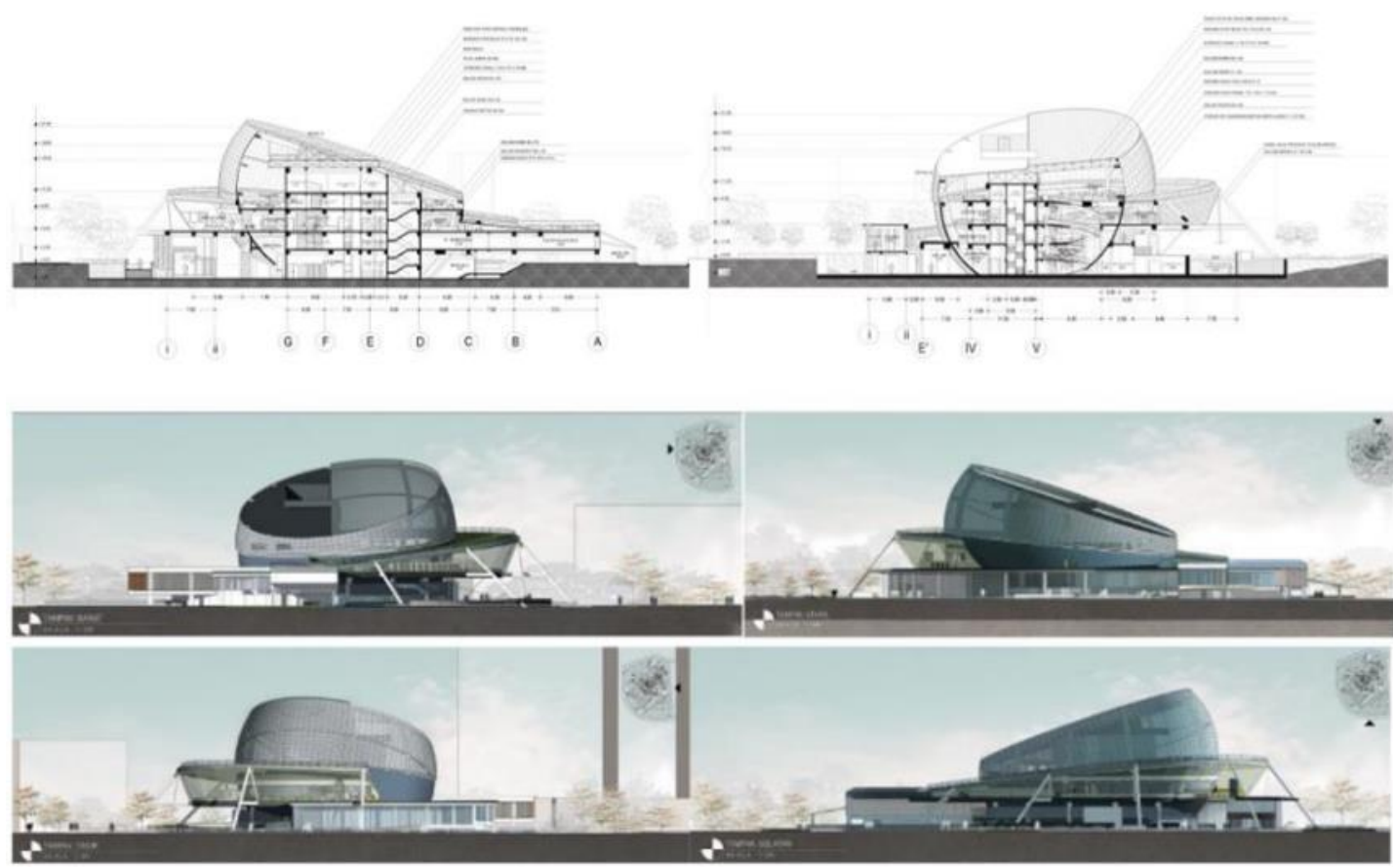

Gambar 7. Potongan dan Tampak Bangunan

Sumber: Penulis, 2019 


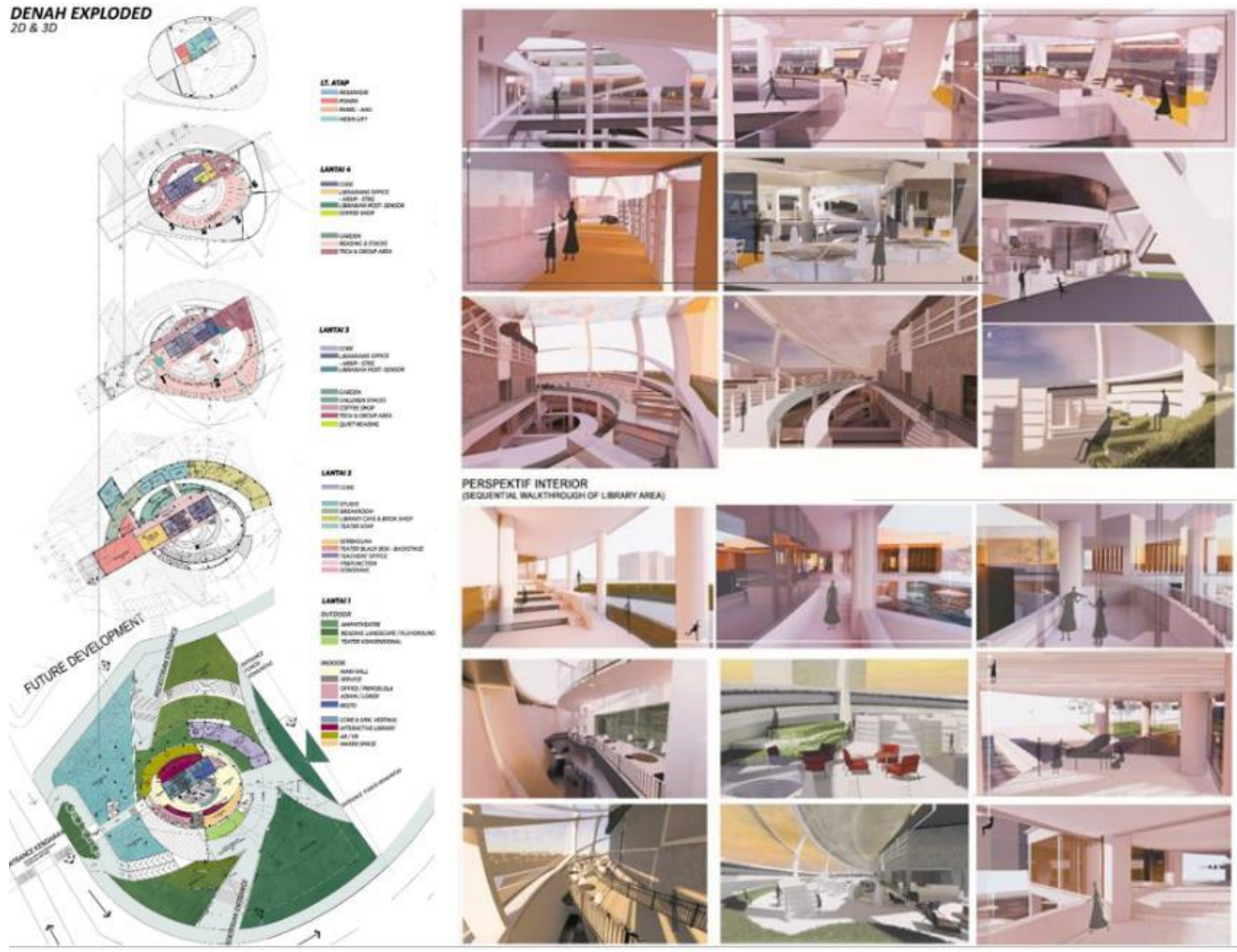

Gambar 8. Denah dan Perspektif Interior Bangunan

Sumber: Penulis, 2019

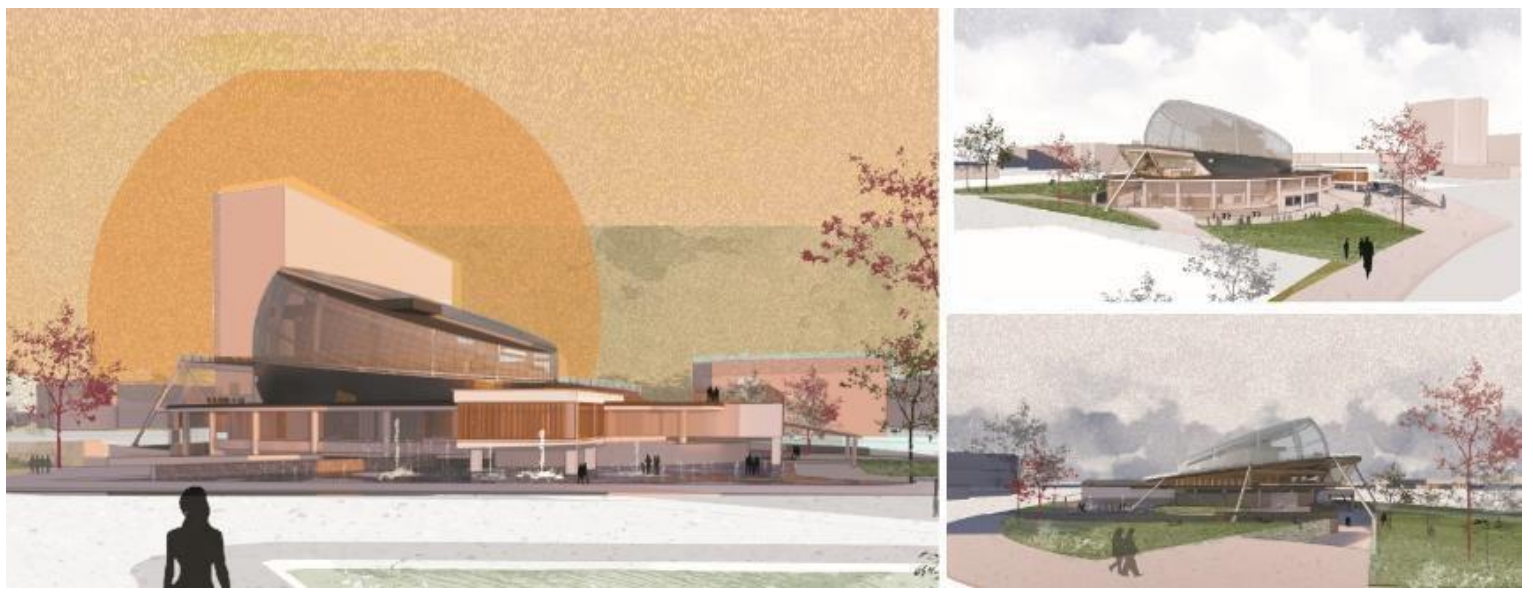

Gambar 9. Perspektif Eksterior Bangunan

Sumber: Penulis, 2019 


\section{KESIMPULAN DAN SARAN}

Kesimpulan

Proyek Fasilitas Edutainment : Perpustakaan Fiksi Hijau dan Ruang Seni Pertunjukan di

Bumi Serpong Damai memiliki 2 tujuan utama :

a. Mengembalikan popularitas perpustakaan dengan memperbarui library experience melalui konsep taman baca (sesuai dengan pergeseran third place ke arah outdoor) dan penunjang berupa art space (art course / event).

b. Mengakomodasi, meningkatkan kualitas dan konseptualitas karya seni, khususnya di bidang literatur dan seni pertunjukan bagi para kreator dan seniman Indonesia.

Perbaikan library experience merupakan sebuah tanggapan pada fenomena The End of The Library, yaitu terdapat penurunan ekstrim pada penggunaan maupun pembelian buku dalam 20-30 tahun terakhir yang dipicu oleh perubahan media konvensional menjadi media digital.

Program Fiction - Garden Library dengan inovasi baru dari bidang desain arsitektur, yang diharapkan dapat merespon ekspektasi pengguna akan library experience yang berbeda, dengan mengangkat konteks reading for pleasure. Program Art Space merupakan suatu upaya meningkatkan kualitas dari perpustakaan sebagai suatu third place melalui universalitas seni, sehingga dapat menambah engagement masyarakat dan komunitas untuk bersosialisasi.

Program-program utama dalam proyek antara lain adalah pelatihan seni literasi dan pertunjukan, ruang perpustakaan berkonsep taman baca, ruang komunal berupa black box theatre (indoor), amphiteatre (outdoor), ruang serbaguna dan ruang diskusi yang masingmasing berperan dalam pencapaian tujuan utama proyek yang telah dikemukakan diatas.

Tapak yang dipilih berlokasi di Jl. Edutown, BSD, Pagedangan, Kabupaten Tangerang. Tapak ini karena peran BSD yang kini telah menjadi kota mandiri dan kota pendidikan. BSD mengalami perkembangan pesat dari segi fasilitas (perumahan, perkantoran, entertain dan pendidikan), unggul dari segi suasananya yang masih belum terlalu ramai kendaraan, berkonsep hijau dan memiliki ketersediaan lahan. Pembangunan proyek di lokasi yang bersangkutan diharapkan dapat membantu pencapaian tujuan proyek itu sendiri, yaitu pusat edutainment (educationentertainment).

\section{Saran}

Saran yang dapat diberikan oleh penulis terkait dengan kesesuaian tapak terhadap studi tipologi. Bahwa hasil dalam studi tipologi ini dapat berubah jika lokasi tapak juga berubah (harus menyesuaikan konteks), sehingga meski objek desain menggunakan metode tipologi yang sama, namun dapat memiliki hasil yang sama sekali berbeda dengan tapak yang berbeda.

\section{REFERENSI}

Andi, J. M. (2018). Transformasi Tempat Ketiga (Third Place). Jurnal Arsir Universitas Muhammadiyah Palembang, Vol.2 (1), E-ISSN 2614-4034.

Badan Pusat Statistik Kabupaten Tangerang : Tangerang dalam Angka 2018. Diakses pada tanggal 30 Desember 2019, dari : https://tangerangkab.bps.go.id/

Bryson, J., Usherwood, B., dan Proctor, R. (2003). Libraries must also be Buildings: New Library Impact Study. London: Resource.

Clark, R.H. dan Pause,M. (1996). Precedent in Architecture. Canada: New Jersey

De Rosa, C. dan Joanne, C. (2005). Perceptions of Libraries and Information Resources. Dublin: Ohio

Erianto, D. (16/09/2015). Artikel ini telah tayang di Kompas.com dengan judul : Popularitas Perpustakaan Semakin Pudar Dilibas Digital. Diakses tanggal 26 Oktober 2019 , dari https://edukasi.kompas.com/read/2015/09/16/09111961/Popularitas.Perpustakaan.Se mak in.Pudar.Dilibas.Digital?page $=$ all

Neufert, E. (2002). Data Arsitek Jilid 2 (Edisi Kedua). Jakarta : Erlangga 
Oldenburg, R. (1989). The Great Good Place: Cafes, Coffee Shops, Community Centers, Beauty Parlors, General Stores, Bars, Hangouts, and How They Get You Through the Day. New York: Paragon House.

Online Computer Library Center, Inc. Diakses pada tanggal 27 Agustus 2019, dari : http://www.oclc.org/reports/pdfs/Percept all.pdf

Pew Research Center. (2013-2018). Dalam artikel yang berjudul : Younger Americans' Library Habits and Expectations, Libraries 2016. Diakses pada 30 Agustus 2019, dari https://www.pewresearch.org/internet/2016/09/09/-libraries-2016.

Picodi. (15/04/2019). Dalam artikel yang berjudul Pembelian Buku di Indonesia (dan di Seluruh Dunia). Diakses pada tanggal 25 Desember 2019, dari https://www.picodi.com/id/mencari-penawaran/pembelian-buku-di-indonesia-dan-diseluruh-dunia

Rossi, A. (1991). Architecture of the City. M.I.T Press: Massachusetts.

Tjahjono, G. (2002). Metode Perancangan Suatu Pengantar untuk Arsitek dan Perancang. Depok: Universitas Indonesia. 